\title{
Agronomic Performance and Dry Matter Yield of Desho (Pennisetum Pedicellatum) and Setaria (Setaria Sphacelata) Grasses Mixed with Greenleaf Desmodium (Desmodium Intortum) at Different Harvesting Time
}

\author{
Minichl Yegrem ${ }^{1 *}$, Berhanu Alemu², Asnakew Awuke² \\ ${ }^{1}$ Salale University Department of Animal Sciences, P.O. Box 245, Fiche, Ethiopia. \\ ${ }^{2}$ Debre markos University Department of Animal Sciences, P.O. Box 269, Debre markos, Ethiopia. \\ *Corresponding Author: Minichl Yegrem, Salale University Department of Animal Sciences, P.O. Box \\ 245, Fiche, Ethiopia.
}

\begin{abstract}
The experiment was conducted to evaluate agronomic performance and dry matter yield of Desho and Setaria grasses mixed with Greenleaf desmodium at different harvesting times. The experiment was conducted using $5 \times 3$ factorial arrangements with five forage stands and three harvesting times. The experiment was arranged in a Randomized Complete Block Design (RCBD) with three replications. The first factors were forage stands (Desho, Setaria, Greenleaf Desmodium, Desho and Setaria grasses mixed with Greenleaf Desmodium). The second factors were harvesting times (90, 120 and 150 days). Data were collected on agronomic performance of forage species. Based on the data collected Harvesting time was significantly $(P<0.01)$ influenced plant height $(P H)$, number of leaves per plant $(N L P)$, number of tillers per plant (NTP) and leaf to stem ratio (LSR). The highest PH, NTP, NLP and DMY were recorded at 150 days. However, highest LSR was recorded at 90 days of harvesting time. The highest dry matter yield (9.44 t/ha) was recorded from Desho mixed with Greenleaf Desmodium at 150 days. Therefore, the results obtained in the current study revealed that Desho mixed with Greenleaf Desmodium could be recommended being the best in improving forage yield at third harvesting times.
\end{abstract}

Keywords: Biomass yield; Grass-legume mixture

\section{INTRODUCTION}

Ethiopia has large livestock population in Africa possessing 60.39 million Cattle, 31.30 million sheep, 32.74 million goats, 2.01 million horses, 8.85 million donkeys, 0.46 million mules, camels 1.42 million and 56.06 million poultry population (CSA, 2018). The livestock sector contributed about 16$25 \%$ of the total Gross Domestic Product (GDP) of the country and 40-44\% of the Agricultural Gross Domestic Product (Stapleton, 2016).

Despite the large number of livestock resources, the productivity is extremely low due to shortage of feeds (Hassen et al., 2010). The availability of feed resource is the most important factor that determines the productivity of livestock (Alemayehu, 2005). According to CSA (2017), Grazing (54.59\%), followed by crops residue $(31.60 \%)$, hay $(6.81 \%)$ and by-products $(1.53 \%)$ were used as animal feeds. Moreover, a very small amount of improved forage $(0.31 \%)$ was used as animal feed and other types of feed that accounted for about $5.11 \%$ were also used in the country. Grazing as a source of livestock feed declined in recent years, due to increased utilization of land for crop cultivation. Moreover, feed supply from natural pasture fluctuates following seasonal dynamics of rainfall (Solomon et al., 2008; Yayneshet, 2010).

The major feed resources are characterized by poor quality and improved forages can be limited in quantity in East Gojjam zone (Addisu et al., 2016). According to the reports of Firew and Getnet (2010), animal feed resources in Gozamen district mainly based on natural pasture grazing and crop residues, which are low in quantity. Forage management tools such as timely harvesting and using grass-legume mixture can achieve optimization of productivity of forages (Bayble et al., 2007). Therefore, one of the alternatives to improve livestock feeding, and thereby their productivity could 
Agronomic Performance, Dry Matter Yield and Nutritional Value of Desho (Pennisetum Pedicellatum) and Setaria (Setaria Sphacelata) Grasses Mixed with Greenleaf Desmodium (Desmodium Intortum) at Different Harvesting Time

be the cultivation of grass-legume mixtures and offer them to animals during critical periods in their production cycle and at times when other sources of feeds are in short supply (Befikadu et al., 2000).

Grass-legume mixtures are preferred due to their several advantages over monoculture that mixing grass with forage legumes can improve biomass of fodder over a pure grass (Ibrahim et al., 2012). Their production potential and utilization under arid conditions are providing low cost fodder to animals particularly during the dry season. Its ease agronomic practices to produce these forage species make them to be a priority choice for the resource poor farmers (Getu et al., 2012).

The use of grasses-legume mixture, Desho (Pennisetum pedicellatum) and Setaria (Setaria sphacelata) mixed with Greenleaf desmodium (Desmodium intortum) for this study is based on their high potential to fill the gap of feed shortage. They are the most promising due to their high agronomic performance and palatability. However, there is limited information on the agronomic performances of Desho and Setaria grasses when grown alone or in mixture with Greenleaf Desmodium. Therefore, this study was designed with the objective of determining the agronomic parameters and dry matter yield of Desho and Setaria mixed with Greenleaf Desmodium and pure stands at different harvesting times.

\section{MATERIALS AND METHODS}

\subsection{Description of the Study Area}

The study was conducted at Debre Markos University, located in Debre Markos town, Gozamin District, East Goijam Zone of Amhara National Regional State. The town is located $300 \mathrm{~km}$ northwest of the capital Addis Ababa and $265 \mathrm{~km}$ Southeast of Bahir Dar, the capital of Amhara National Regional State. It is situated at an altitude of 2446 meters above sea level. The highest monthly rainfalls of the area recorded were $259.08 \mathrm{~mm}$ in May and $243.84 \mathrm{~mm}$ in July, but no rainfall was recorded in December and January. The town has $1182.78 \mathrm{~mm}$ annual rainfall and minimum and maximum temperatures of $11.1^{\circ} \mathrm{C}$ and $22.9^{\circ} \mathrm{C}$, respectively.

\subsection{Land Preparation, Planting and Experimental Materials}

Planting materials, the grass species (Setaria and Desho) and Legume (Greenleaf Desmodium) were collected from Debre Markos University grass nursery site and Finote Selam, respectively. Land ploughing and bed preparation were made in July 2017. After preparing a fine bed, planting, was done in August 2017, the planting materials for the two grass species were root splits whereas; the planting material for legume specie was root cutting.

\subsubsection{Experimental Layout, Design and Treatments}

The study was conducted using $5 \times 3$ factorial arrangements in randomized complete block design (RCBD). Planting materials (Desho, Setaria, Greenleaf Desmodium, Desho and Setaria mixed with Greenleaf Desmodium) and three harvesting times (90, 120 and 150 days) were considered as factors. The spaces between row and plant for Desho and Setaria grasses were $75 \mathrm{~cm}$ by $50 \mathrm{~cm}$, respectively and Greenleaf Desmodium was planted at the side of grass in the same row. The experiment consisted of three replications with 15 treatment combinations. The spaces between replications and plots were $1.5 \mathrm{~m}$ and $0.5 \mathrm{~m}$, respectively. Each experimental unit had $3 * 3 \mathrm{~m}$ with a total area of $9 \mathrm{~m}^{2}$. The total area of the experimental site was $624 \mathrm{~m}^{2}(12 \mathrm{~m} \times 52 \mathrm{~m})$. Each plot had five rows on which plantings were planted uniformly. The treatment combinations are indicated in Table 1.

Table1. Treatment combinations.

\begin{tabular}{|c|c|c|c|c|c|}
\hline \multirow{2}{*}{ Harvesting times } & \multicolumn{5}{|c|}{ Grass, legume and their mixtures } \\
\cline { 2 - 6 } & $\begin{array}{c}\text { Desmodium } \\
\text { Intortum }\end{array}$ & Desho & Setaria & $\begin{array}{c}\text { Desho+ } \\
\text { D. Intortum }\end{array}$ & $\begin{array}{c}\text { Setaria+ } \\
\text { D. Intortum }\end{array}$ \\
\hline Harvesting time 1 & DeHT1(T1) & DsHT1(T4) & StHT1(T7) & DsDeHT1(T10) & StDeHT1 (T13) \\
\hline Harvesting time 2 & DeHT2(T2) & DsHT2(T5) & StHT2(T8) & DsDeHT2(T11) & StDeHT2 (T14) \\
\hline Harvesting time3 & DeHT3(T3) & DsHT3(T6) & StHT3(T9) & DsDeHT3(T12) & StDeHT3 (T15) \\
\hline
\end{tabular}

DeH1(T1)=Desmodium intortum with harvesting time1; DeHT1(T2)=Desmodium intortum with harvesting time2;DeHT2(T2)=Desmodium intortum with harvesting time3; DeHT3(T3)=Desmodium intortum with harvesting time3; DsHT1(T4)= Desho with harvesting time1; DsHT2 (T5)= Desho with harvesting time2; DsHT3 (T6)= Desho with harvesting time3; StHT1(T7)= Setaria with harvesting time1; StHT2(T8)=Setaria wit $h$ harvesting time2; StHT3(T9) = Setaria with harvesting time3; DsDeHT1(T10)=Desho+Desmodium intortum with harvesting time1; DsDeHT2(T11)=Desho + Desmodium intortum with harvesting time 2; DsDeHT3(T12) =Desho+Desmodium intortum with harvesting time3; StDeHT1(T13)= Setaria+ Desmodium Intortum with harvesting time1; StDeHT2(T14) = Setaria+ Desmodium Intortum with harvesting time $;$ StDeHT3(T15) = Setaria + Desmodium Intortum with harvesting time3

International Journal of Research Studies in Agricultural Sciences (IJRSAS)

Page | 32 
Agronomic Performance, Dry Matter Yield and Nutritional Value of Desho (Pennisetum Pedicellatum) and Setaria (Setaria Sphacelata) Grasses Mixed with Greenleaf Desmodium (Desmodium Intortum) at Different Harvesting Time

\subsubsection{Data Collection}

Leaf area (LA), Leaf to stem ratio, leaf number per plant (LNPP) and number of tillers per plant (NTPP) were recorded for grasses and number of branches for legume at different harvesting times. Plant height was measured for grasses and legume at harvesting times. It was measured from the ground to the tip of the highest leaf of the plant for each plot.

Leaf area was calculated by multiplying leaf length and maximum width by 0.75 using the formula of Watson and Watson (1954). Number of Tillers and branches were recorded by direct counting of tillers and branches for grasses and legume, respectively.

Harvesting was done by hand using a sickle at a height of $5 \mathrm{~cm}$ from ground level. Ten plants were selected from each plot for recording data at each harvesting time for all parameters.

Representative $250 \mathrm{~g}$ fresh samples were taken for dry matter determination. It was determined by harvesting the grasses and legume at three harvesting times from an area of $3 \mathrm{~m}^{2}$ from 3 central rows. A fresh sample of each species was put into a plastic bag and the fresh weight was taken in the field using sensitive balance. The dry matter yield was calculated after drying the samples in a forced drying oven adjusted at a temperature of $65^{\circ} \mathrm{C}$ for $72 \mathrm{~h}$. DM yield was calculated as:

DM yield (t/ha) $=(10 \times$ TFW x SSDW) $/($ HA x SSFW $)($ James 2008)

Where:

$10=$ constant for conversion of yields in $\mathrm{kg} / \mathrm{m}^{2}$ to tone $/ \mathrm{ha}$;

TFW = total fresh weight $(\mathrm{kg})$;

SSDW = sub-sample dry weight $(\mathrm{g})$;

$\mathrm{HA}=$ harvest area $\left(\mathrm{m}^{2}\right)$, and

SSFW = sub-sample fresh weight $(\mathrm{g})$

\subsection{Statistical Analysis}

Data analysis was subjected to analysis of variance using the General Linear Model procedure of the statistical analysis system (SAS, version 9.2). Differences among treatment means were separated using Duncan's Multiple Range Test (DMRT), when treatment effects are significant $(\mathrm{P}<0.05)$. The statistical model was used for this design:

$\mathrm{Y}_{\mathrm{ijk}}=\mu+\mathrm{r}_{\mathrm{i}}+\mathrm{S}_{\mathrm{j}}+\mathrm{H}_{\mathrm{k}+} \mathrm{SH}_{\mathrm{jk}}+\mathrm{e}_{\mathrm{ijk}}$ Where,

$\mathrm{Y}_{\mathrm{ijk}}=$ the response variable

$\mu=$ overall mean

$r_{i}={ }_{i}^{\text {th }}$ replication effect

$\mathrm{S}_{\mathrm{j}=\mathrm{j}}{ }^{\text {th }}$ factor effect (forage stands)

$\mathrm{H}_{\mathrm{k}=\mathrm{K}}{ }^{\text {th }}$ factor effect (Harvesting times)

$\mathrm{SH}_{\mathrm{jk}}={ }_{\mathrm{jk}}{ }^{\text {th }}$ interaction effect (Forage stands $\mathrm{X}$ Harvesting times)

$\mathrm{e}_{\mathrm{ijk}}=$ random error

\section{RESUltS}

\subsection{Morphological Parameters}

\subsubsection{Plant height}

Plant height was significantly affected $(\mathrm{P}<0.01)$ by harvesting time and forage stands but interaction effect showed non-significant effect (Table 2). The highest plant height $(54.3 \mathrm{~cm})$ was recorded at $150^{\text {th }}$ days, while lowest plant height was obtained at $90^{\text {th }}$ day age for grasses.. Concerning forage stands, significant differences were observed between Setaria and Desho grasses. But, there was no significant difference between pure stands of grasses and their mixtures with Greenleaf Desmodium on plant height. Accordingly, the highest plant height $(48.4 \mathrm{~cm})$ and $(50.7 \mathrm{~cm})$ was recorded for $\mathrm{St}$ and StDe, respectively, while the least plant height $(41.1 \mathrm{~cm})$ and $(45.8 \mathrm{~cm})$ were obtained from Ds and DsDe, respectively 
Agronomic Performance, Dry Matter Yield and Nutritional Value of Desho (Pennisetum Pedicellatum) and Setaria (Setaria Sphacelata) Grasses Mixed with Greenleaf Desmodium (Desmodium Intortum) at Different Harvesting Time

Table2. Plant height (cm) as affected by harvesting time and forage stand

\begin{tabular}{|c|c|c|}
\hline Forage stands & Grasses & Legume \\
\hline Desho & $41.1^{\mathrm{c}}$ & - \\
\hline Setaria & $48.4^{\mathrm{ab}}$ & - \\
\hline Desho with Desmodium & $45.8^{b}$ & $43.9^{b}$ \\
\hline Setaria with Desmodium & $50.7^{\mathrm{a}}$ & $43.8^{b}$ \\
\hline Desmodium & - & $45.6^{\mathrm{a}}$ \\
\hline \multirow[t]{2}{*}{ P-value } & $<0.0001$ & $<0.0001$ \\
\hline & Harvesting times & \\
\hline 90 days & $39.7^{c}$ & $26.8^{c}$ \\
\hline 120 days & $45.5^{b}$ & $42.8^{b}$ \\
\hline 150 days & $54.3^{\mathrm{a}}$ & $63.7^{\mathrm{a}}$ \\
\hline $\mathrm{CV}$ & 5.67 & 1.53 \\
\hline SEM & 2.63 & 0.680 \\
\hline $\mathrm{p}$-value & $<0.0001$ & $<0.0001$ \\
\hline
\end{tabular}

abc means the main factors and interactions means with similar superscripts in columns or rows are not significantly different at $(P>0.05)$; $C V=$ coefficient of variation; SEM=standard error of mean;

In the case of Desmodium, significantly higher value of plant height $(45.6 \mathrm{~cm})$ was recorded from sole desmodium compared to desmodium grown mixed with either Setaria or Desho grasses. But Desmodium grown mixed with Setaria and Desho grasses had showed statistically similar values.

\subsubsection{Number of Tillers and Leaf Area}

Number of tillers and branches per plant were significantly $(\mathrm{P}<0.01)$ affected by species, harvesting time and their interaction (Table 4). Ds (51.2) and DsDe (64.8) had higher number of tillers as compared with St (30.8) and StDe (37.0). In case of harvesting time, the highest (72.43) tillers were recorded at the third harvesting time $\left(150^{\text {th }}\right.$ days $)$, whereas, the least $(17.0)$ number of tillers were recorded at the first harvesting time $\left(90^{\text {th }}\right.$ days $)$.

Accordingly, the interaction effects showed the highest numbers of tillers (108.8) for DsDeHT3. At the 90 days of harvesting, pure grass species (Desho and Setaria) and grass-legume mixtures (Desho or setaria mixed with desmodium) did not show statistical differences ( $\mathrm{P}>0.05)$, but at 120 and 150 days of harvesting Ds and DsDe showed higher values compared to St and StDe. Non- Significant difference $(\mathrm{P}>0.05)$ was observed between pure stand of grasses and their mixture with Greenleaf Desmodium on number of tiller at first and second harvesting time, while significant differences $(\mathrm{P}<0.01)$ were observed between DsHT3 and DsDeHT3.

The leaf area showed significant difference $(\mathrm{P}<0.01)$ by the effect of harvesting times, forage species and their interaction $(\mathrm{P}<0.05)$ (Table 5). The highest $\left(30.2 \mathrm{~cm}^{2}\right)$ leaf area was recorded at the third harvesting time (150 days) whereas; the least $\left(22.5 \mathrm{~cm}^{2}\right)$ leaf area was recorded at the first harvesting time (90 days). In case of interaction effect, the maximum leaf area was recorded for StH3 $\left(44.7 \mathrm{~cm}^{2}\right)$ and StDeH3 $\left(46.4 \mathrm{~cm}^{2}\right)$, while the minimum leaf area was recorded for Ds and DsDe at all harvesting time. Generally, Setaria grass had higher leaf area as compared with Desho grass.

Table4. Leaf area (cm2) and number of tillers of grasses as influenced by species, harvesting time and their interaction

\begin{tabular}{|c|c|c|c|c|c|c|c|c|}
\hline \multirow{3}{*}{$\begin{array}{l}\text { Forage } \\
\text { Stands }\end{array}$} & \multicolumn{8}{|c|}{ Harvesting times } \\
\hline & \multicolumn{4}{|c|}{ Leaf area } & \multicolumn{4}{|c|}{ Number of tillers } \\
\hline & HT1 & HT2 & HT3 & Mean & HT1 & HT2 & HT3 & Mean \\
\hline Ds & $14.3^{\mathrm{e}}$ & $17.7^{\mathrm{e}}$ & $14.4^{\mathrm{e}}$ & $15.5^{\mathrm{b}}$ & $14.8^{\mathrm{e}}$ & $59.6^{\text {bc }}$ & $79.3^{b}$ & $51.2^{\mathrm{b}}$ \\
\hline St & $30.3^{d}$ & $38.8^{\mathrm{c}}$ & $44.7^{\mathrm{ab}}$ & $38.0^{\mathrm{a}}$ & $14.2^{\mathrm{e}}$ & $32.8^{\mathrm{de}}$ & $45.3^{\mathrm{cd}}$ & $30.8^{\mathrm{c}}$ \\
\hline DsDe & $15.8^{\mathrm{e}}$ & $20.0^{\mathrm{e}}$ & $15.0^{\mathrm{e}}$ & $16.9^{b}$ & $19.1^{\mathrm{e}}$ & $66.3^{\mathrm{bc}}$ & $108.8^{\mathrm{a}}$ & $64.8^{\mathrm{a}}$ \\
\hline StDe & $29.8^{\mathrm{d}}$ & $39.7^{\mathrm{bc}}$ & $46.4^{\mathrm{a}}$ & $38.6^{\mathrm{a}}$ & $19.7^{\mathrm{e}}$ & $34.9^{\mathrm{de}}$ & $56.4^{\mathrm{c}}$ & $36.97^{\mathrm{c}}$ \\
\hline Mean & $22.5^{\mathrm{c}}$ & $29.1^{b}$ & $30.2^{\mathrm{a}}$ & 27.3 & $17.0^{\mathrm{c}}$ & $48.4^{b}$ & $72.4^{\mathrm{a}}$ & 45.9 \\
\hline \multicolumn{5}{|c|}{$\mathrm{SEM}=3.11$} & \multicolumn{4}{|c|}{ SEM=11.8 } \\
\hline \multicolumn{5}{|c|}{$\mathrm{CV}=11.4$} & \multicolumn{4}{|c|}{$\mathrm{CV}=25.7$} \\
\hline \multicolumn{9}{|c|}{$\mathrm{P}$-value } \\
\hline \multicolumn{5}{|c|}{$=<.0001$} & \multicolumn{4}{|c|}{ FS } \\
\hline
\end{tabular}


Agronomic Performance, Dry Matter Yield and Nutritional Value of Desho (Pennisetum Pedicellatum) and Setaria (Setaria Sphacelata) Grasses Mixed with Greenleaf Desmodium (Desmodium Intortum) at Different Harvesting Time

\begin{tabular}{|c|c|c|}
\hline HT $=<.0001$ & HT $\quad=<.0001$ \\
\hline FS X HT $=0.0101$ & & FS X HT $=<.0055$ \\
\hline
\end{tabular}

abcde means with similar superscripts in columns or rows are not significantly different at $(P>0.05)$; De=Greenleaf Desmodium ; $C V=$ coefficient of variation; SEM =standard error of mean; Ds = Desho; St = Setaria; StDe = Setaria mixed with desmodium; DsDe=Desho mixed with desmodium; FS= forage stands (Setaria, Desho, Desmodium, Setaria and Desho mixed with Greenleaf Desmodium); HT1 - HT3 = Harvesting times $1-3$; FS $x$ HTs = interaction

\subsection{Leaf to Stem Ratio and Number of Branches}

Leaf to stem ratio was significantly affected $(\mathrm{P}<0.01)$ by harvesting times, but forage stands and their interaction with harvesting time was showed non-significant effect $(\mathrm{P}>0.05)$ (Table 5). The highest leaf to stem ratio (2.04) was recorded at $90^{\text {th }}$ days harvesting time while the least (1.14) was recorded at $150^{\text {th }}$ days harvesting time.

Table5. Leaf to stem ratio for grasses and Numbers of branches for legume affected by grass-legume mixtures and harvesting times

\begin{tabular}{|c|c|c|}
\hline \multicolumn{3}{|c|}{ Parameters } \\
\hline Forage stands & $\begin{array}{c}\text { Leaf to stem } \\
\text { Ratio }\end{array}$ & $\begin{array}{c}\text { Numbers of } \\
\text { Branches }\end{array}$ \\
\hline Desho & 1.47 & - \\
\hline Setaria & 1.62 & - \\
\hline Desho with Desmodium & 1.44 & $20.5^{b}$ \\
\hline Setaria with Desmodium & 1.63 & $19.5^{\mathrm{bc}}$ \\
\hline Greenleaf Desmodium & - & $21.7^{\mathrm{a}}$ \\
\hline $\mathrm{P}$ - value & Ns & $<0.0001$ \\
\hline \multicolumn{3}{|c|}{ Harvesting times } \\
\hline 90 days & $2.04^{\mathrm{a}}$ & $6.11^{c}$ \\
\hline 120 days & $1.45^{b}$ & $19.9^{b}$ \\
\hline 150 days & $1.14^{\mathrm{b}}$ & $35.7^{\mathrm{a}}$ \\
\hline $\mathrm{CV}$ & 27.6 & 6.67 \\
\hline SEM & 0.440 & 1.36 \\
\hline p-value & 0.0001 & $<0.0001$ \\
\hline
\end{tabular}

${ }^{a b c}$ means the main factors with similar superscripts in columns are not significantly different at $(P>0.05)$; $n s=$ non significant $C V=$ coefficient of variation; $S E M=$ standard error of mean; HT1 - HT3 = Harvesting times $1-3$

Sole Desmodium was showed significantly $(\mathrm{P}<0.01)$ higher mean number of branches as compared to Desmodium mixed with grasses, while no significant difference $(\mathrm{P}>0.05)$ was recorded between Greenleaf Desmodium mixed with Setaria and Desho grasses. This may be due to the fact that no competition of light, nutrient uptake with grasses in sole Greenleaf Desmodium. The highest values of number of branches (35.7) were recorded at the third harvesting times (150 days, while the least number of branches (6.11) were recorded at the first harvesting times (Table 4).

\subsubsection{Number of Leaves per Plant}

Harvesting times, forge stands and their interaction showed significant difference $(\mathrm{P}<0.01)$ on number of leaves per plant as indicated (Table 6). The number of leaves per plant at the 90,120 and 150 days of harvesting time were 84.8, 242 and 362, respectively. Accordingly, large numbers of leaves per plant were recorded at the third harvesting times as compared to first and second harvesting times.

Table6. Number of leaves of grasses as influenced by species, harvesting time and their interaction

\begin{tabular}{|c|c|c|c|c|}
\hline \multirow{2}{*}{$\begin{array}{c}\text { Experimental } \\
\text { Plants }\end{array}$} & \multicolumn{4}{|c|}{ Harvesting stages } \\
\cline { 2 - 5 } & HT1 & HT2 & HT3 & Mean \\
\hline Ds & $74.2^{\mathrm{e}}$ & $298^{\mathrm{bc}}$ & $397^{\mathrm{b}}$ & $256^{\mathrm{b}}$ \\
\hline St & $71.2^{\mathrm{e}}$ & $164^{\mathrm{de}}$ & $226^{\mathrm{cd}}$ & $34^{\mathrm{c}}$ \\
\hline DsDe & $95.7^{\mathrm{e}}$ & $332^{\mathrm{bc}}$ & $544^{\mathrm{a}}$ & $184^{\mathrm{c}}$ \\
\hline StDe & $98.3^{\mathrm{e}}$ & $174^{\mathrm{de}}$ & $282^{\mathrm{c}}$ & 230 \\
\hline Mean & $84.8^{\mathrm{c}}$ & $242^{\mathrm{b}}$ & $362^{\mathrm{a}}$ & \\
\hline
\end{tabular}


Agronomic Performance, Dry Matter Yield and Nutritional Value of Desho (Pennisetum Pedicellatum) and Setaria (Setaria Sphacelata) Grasses Mixed with Greenleaf Desmodium (Desmodium Intortum) at Different Harvesting Time

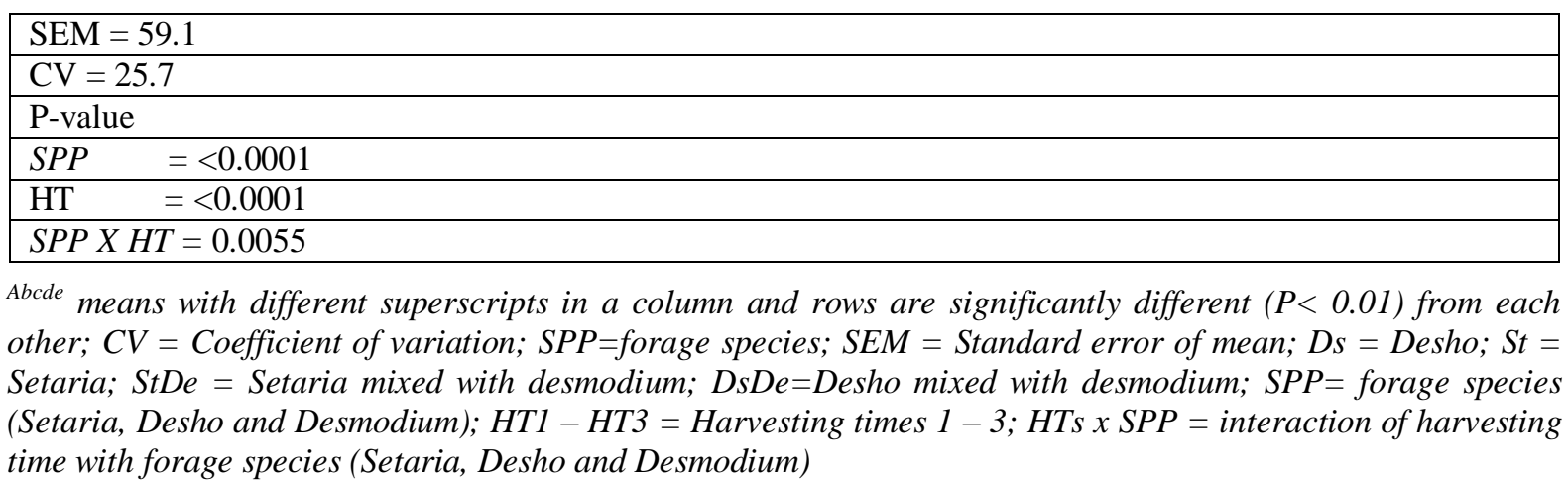

With regard to interaction effect, the highest numbers of leaves were recorded for DsHT3 (396.61) and DsDeHT3 (544). At 90 days of harvesting Desho, Setaria and their mixtures with Greenleaf desmodium did not show statistical differences ( $>>0.05)$ while at 120 and 150 days of harvesting Ds and DsDe showed higher values of number of leaves as compared to St and StDe.

\subsubsection{Dry Matter Yield per Hectare}

There were significant differences $(\mathrm{P}<0.01)$ in DMY due to harvesting times, forage stands and their interactions (Table). The highest $(9.44 \mathrm{t} / \mathrm{ha})$ DMY was recorded from DsDeHT3 followed by StDeHT3 (8.26 t/ha), while the least dry matter yield was obtained from StHT1 (1.76 t/ha) and DeHT1 $(1.53 \mathrm{t} / \mathrm{ha})$. As regards harvesting time, the highest DMY $(6.08 \mathrm{t} / \mathrm{ha})$ was recorded at the third harvesting time (150 days, while the least $(2.45 \mathrm{t} / \mathrm{ha})$ value was recorded from the first harvesting time, confirming the potential effect of harvesting time on DMY.

Table7. Dry matter yield as influenced by forage stands, harvesting time and their interactions

\begin{tabular}{|c|c|c|c|c|}
\hline \multirow{2}{*}{$\begin{array}{c}\text { Experimental } \\
\text { Plants }\end{array}$} & \multicolumn{4}{|c|}{ Harvesting stages } \\
\hline & HT1 & HT2 & HT3 & Mean \\
\hline Ds & $2.18^{\mathrm{fg}}$ & $3.22^{\mathrm{ef}}$ & $5.13^{\mathrm{cd}}$ & $3.51^{\mathrm{c}}$ \\
\hline St & $1.76^{\mathrm{g}}$ & $2.45^{\mathrm{fg}}$ & $3.98^{\mathrm{de}}$ & $2.73^{\mathrm{d}}$ \\
\hline DsDe & $3.47^{\mathrm{ef}}$ & $5.84^{\mathrm{c}}$ & $9.44^{\mathrm{a}}$ & $6.25^{\mathrm{a}}$ \\
\hline StDe & $3.30^{\mathrm{ef}}$ & $4.90^{\mathrm{cd}}$ & $8.26^{\mathrm{b}}$ & $5.49^{b}$ \\
\hline $\mathrm{De}$ & $1.53^{\mathrm{g}}$ & $2.73^{\text {efg }}$ & $3.58^{\mathrm{ef}}$ & $2.62^{\mathrm{d}}$ \\
\hline Mean & $2.45^{\mathrm{c}}$ & $3.82^{b}$ & $6.08^{\mathrm{a}}$ & 4.12 \\
\hline \multicolumn{5}{|l|}{$\mathrm{SEM}=0.580$} \\
\hline \multicolumn{5}{|l|}{$\mathrm{CV}=14.1$} \\
\hline \multicolumn{5}{|l|}{$\mathrm{P}$-value } \\
\hline \multicolumn{5}{|c|}{$\mathrm{FS} \quad=<.0001$} \\
\hline \multicolumn{5}{|c|}{ HT $\quad=<.0001$} \\
\hline $\mathrm{FS} \mathrm{X} \mathrm{HT}=<.0$ & & & & \\
\hline
\end{tabular}

abcdefg, means with similar superscripts in columns or rows are not significantly different at $(P>0.05)$; De=Desmodium intortum; $C V=$ coefficient of variation; SEM =standard error of mean; Ds = Desho; St = Setaria; StDe = Setaria mixed with desmodium; DsDe=Desho mixed with desmodium; FS = forage stands (Setaria, Desho, Desmodium, Setaria and, Desho mixed with Desmodium); HT1 - HT3 = Harvesting times 1 3; HTs $x$ FS = interactions

Desho and Setaria mixed with Greenleaf Desmodium resulted in significantly higher $(\mathrm{P}<0.01)$ DMY than their pure stands. DsDe was showed the highest DMY (6.25 t/ha) as compared with other species and combinations.

\section{DISCUSSION}

The effect of harvesting time was significant for all agronomic properties. Plant height, number of leaf, number of tiller and leaf area tended to increase with advanced plant maturity, while leaf to stem ratios tended to decrease. Therefore, agronomic performance of forage grasses and legume were adversely affected by plant age, despite higher values in most parameters. This might be due to, as harvesting time increase the root system of forage becomes well developed resulting high nutrient uptake ability. The current result is similar with other researchers, Bimrew (2016), Genet et al. (2017); they stated that that number of leaves, plant height and number of tillers of Desho grass was 
Agronomic Performance, Dry Matter Yield and Nutritional Value of Desho (Pennisetum Pedicellatum) and Setaria (Setaria Sphacelata) Grasses Mixed with Greenleaf Desmodium (Desmodium Intortum) at Different Harvesting Time

increased with advanced maturity of age, and lower leaf to stem ratio values. The decrease in leaf to stem ratio with increasing age might be due to the harvesting age increased the grasses becomes stemy which decreased leaf to stem ratio.

Results indicated that investigated the highest plant height was obtained at later time of harvesting. In the current study the enhanced plants height was observed after the $90^{\text {th }}$ days of plant growth with the highest increment being observed starting from the second to the third harvesting times. The reasons for the rapid increment of grasses at this time could be due to the increment of well established plant roots, which can quest nutrients from the deeper parts of the soil. Similarly, Ansah et al. (2010) reported increasing plant height through increased harvesting day on four varieties of Napier grass.

The highest mean plant height value was obtained for Setaria grass compared to Desho grass. The variation in plant height observed in different Species in the current study might be attributed to the variations in genetic makeup of the Species, soil and environmental adaptability (Zaman, 2006). Moreover, it might be due to the relatively less number of tillers and leaves in Setaria in which the nutrients are used for height increment rather than tiller production. Contrary to this, the short plant height observed in Desho could be due to the production of high number of tiller, which could share the available soil nutrient that could be used for growth. In case of Desmodium, the highest plant height was recorded from sole desmodium compared to desmodium grown mixed with either Setaria or Desho grasses. But Desmodium grown mixed with Setaria and Desho grasses had showed statistically similar values indicating absence of competition for resources especially for light in pure stand of Greenleaf Desmodium.

Number of tillers increased with the prolonged maturity. The rates of increase in the number of tillers were faster till 120 days of establishment though the number of tillers tended to increase at a decreasing rate during the last month of the experimental period. Higher increment of tiller density observed at the second harvesting time (120 days) might be due to more vegetative growth of the grass resulting from its well establishment at this age. Generally, from these values it is clearly observed that the number of tillers increased through the first harvesting time to third harvesting time. This result agrees with those of Rambau et al. (2016) and Ali et al. (2010) who reported an increased number of tillers with an increased in harvest days on Napier grass and Setaria grass, respectively. The maximum leaf area was recorded for Setaria grass, while the minimum leaf area was recorded for Desho grass at all harvesting time. Generally, Setaria grass had higher leaf area as compared with Desho grass. The difference in leaf area in the current study might be due to species variations.

The highest leaf to stem ratio was recorded at the first harvesting time while the least was recorded at the third harvesting time. The reduction of the leaf to stem ratio might be due to the reduction of leaf as the plants advance in age of maturity. This result agrees with the finding of Ali et al. (2010) who reported that leaf to stem ratio decreased from early clipping to late clipping on setaria grass.

Grass-Legume mixtures had an effect on forage DMY. In general, it was observed that grass-legume mixture produced more yield in comparison with the grass only (control). In the current study, highest DMY was obtained in the Desho grass mixed with Greenleaf Desmodium at 150 days whereas the lowest DM yield was recorded in the controls (setaria grass and Greenleaf Desmodium alone). This finding is in agreement with the study of Sturludottir et al. (2013), who reported that on average, the legume-grass mixture plots had more DMY than the most productive monoculture. The attainment of high DMY in the grass-legume mixture may be attributed to beneficial effects of mixing grasses and legumes and also from the differences in the harvesting time growth pattern between the grass and legume species. This indicated that DMY increased with increasing harvesting time. This might be due to the development of additional tiller, leaf formation, leaf elongation, stem development and vegetative growth of the plant. Moreover, increment of forage yield was found to be directly proportional to increasing plant height and numbers of tillers/plant (Shah et al., 2015; Aysen and Ferda, 2012).

In conclusion the morphological traits such as plant height, number of tillers per plant, number of branches per plant, and number of leaves per plant of forage stands were increased as harvesting time increased. The highest DMY was recorded at 150 days of harvesting from Desho mixed with Greenleaf Desmodium. The mixture of grasses and legume may increase the agronomic performance 
Agronomic Performance, Dry Matter Yield and Nutritional Value of Desho (Pennisetum Pedicellatum) and Setaria (Setaria Sphacelata) Grasses Mixed with Greenleaf Desmodium (Desmodium Intortum) at Different Harvesting Time

of grasses. Moreover, improvement in biomass yield due to mixing of grasses (Desho and Setaria) with legume (Greenleaf Desmodium) has been noticed in the current study. Therefore, Desho mixed with Greenleaf desmodium with the third harvesting time would be recommended based on biomass yield

\section{REFERENCES}

[1] Addisu Endalew; Firew Tegegne and Getnet Assefa. 2016. Constraints and Opportunities on Production and Utilization of Improved Forages in East Gojjam Zone, Amhara Region, Ethiopia: Journal of Biology, Agriculture and Healthcare. 6(9): 136-152.

[2] Alemayehu Mengistu. 2005. Feed resources base of Ethiopia: Status and opportunities for integrated development. 377-386P. In Proceedings of the $12^{\text {th }}$ Annual Conference of the Ethiopian Society of Animal Production (ESAP). Addis Ababa, Ethiopia, August 12-14.

[3] Ali M A; Ishaque M M and Haji A B. 2010. Growth and Herbage Yield of Setaria Sphacelata Grass in Response to Varying Clipping Stages. The Journal of Animal \& Plant Sciences. 20(4): 261-265.

[4] Ansah T; Osafo E L and Hansen H H. 2010. Herbage yield and chemical composition of four varieties of Napier (Pennisetum purpureum) grass harvested at three different days after planting. Agric. and Biol. J. of North Am. 1(5):923-929.

[5] Aysen U and Ferda A. 2012. The effect of mixture rates and cutting stages on some yield and quality characters of pea (Pisum sativum L.) + oat (Avena sativa L.) mixture Turkish Journal of Field Crops. 17(1): 62-66.

[6] Bayble T; Melaku S and Prasad N K. 2007. Effects of cutting dates on nutritive value of Napier (Pennisetum purpureum) grass planted sole and in association with Desmodium (Desmodium intortum) or Lablab (Lablab purpureus). Livestock Research for Rural Development. Volume 19, Article \#11. Retrieved April 30, 2018, from http://www.lrrd.org/lrrd19/1/bayb19011.htm.

[7] Befekadu Degefe and Berhanu Nega. 2000. The Ethiopian Economic Association. Annual Report on the Ethiopian Economy, Volume I. Addis Ababa, Ethiopia.

[8] Bimrew Asmare. 2016. Evaluation of the Agronomic, Utilization, Nutritive and Feeding Value of Desho Grass (Pennisetum pedicellatum). PhD. Dissertation. Jimma University, Jimma, Ethiopia. 127p.

[9] CSA (Central Statistical Agency). 2017. Agricultural Sample Survey. Report on livestock and livestock characteristics (Private peasant holdings), volume II, Statistical Bulletin, 585.Addis Ababa, Ethiopia.194p.

[10] CSA (Central Statistical Agency). 2018. Agricultural Sample Survey. Report on livestock and livestock characteristics (Private peasant holdings), volume II, Statistical Bulletin, 587.Addis Ababa, Ethiopia.100p.

[11] Firew Tegegne and Getnet Assefa. 2010. Feed resource assessments in Amhara National Regional State. Ethiopian Sanitary and phyto-sanitary standards and livestock and meat marketing program (SPS-LMM) Texas A and M University system Addis Ababa, Ethiopia. 106p.

[12] Genet Tilahun; Bimrew Asmare and Yeshambel Mekuriaw. 2017. Effects of harvesting age and spacing on plant characteristics, chemical composition and yield of desho grass (Pennisetum pedicellatum Trin.) in the highlands of Ethiopia. Tropical Grasslands-Forrajes Tropicales. ; DOI: 10.17138/TGFT. 5(2): 77-84.

[13] Getu K; Mesfin D; Aemiro K and Getnet A. 2012. Comparative evaluation of tree lucerne (Chamaecytisuspalmensis) over conventional protein supplements in supporting growth of yearling horro lambs. Livestock Research for Rural Development. Volume 24, Article 8.Retrieved January 11 2017, from http: //www.lrrd.org/lrrd24/1/getu24008.htm.

[14] Hassen A; Ebro A; Kurtu M and Treydte A C. 2010. Livestock feed resources utilization and management as influenced by altitude in the Central Highlands of Ethiopia. Livestock Research for Rural Development. Volume 22, Article \#229. Retrieved December 23, 2017, from http://www.lrrd.org/lrrd22/12/hass22229.htm

[15] Ibrahim M; Ayub M; Tanveer A and Yaseen M. 2012. Forage quality of maize and legumes as monocultures and Mixtures at different seed ratios. The Journal of Animal \& Plant Sciences. 22(4): 987-992.

[16] James K; Daniel M; Mugendi N. 2008. Combining Napier grass with leguminous shrubs in counter hedgerows controls soil erosion without competing with crops.

[17] Rambau M D; Fushai F and Baloyi J. 2016. Productivity, chemical composition and rumen degradability of irrigated Napier grass leaves harvested at three stages of maturity. South African Journal of Animal Science. 46(4): 398-408.

[18] SAS (Statistical Analysis System). 2002. SAS Institute Inc., Version 9.1, Cary, NC, USA.

[19] Shah S; Akhtar L H; Minhas R; Bukhari M S; Ghani A and Anjum M H. 2015. Evaluation of different oat (Avena sativa L.) varieties for forage yield and related characteristics. Sci Lett. 3(1): 13-16.

[20] Solomon Bogale;Solomon Melaku and Alemu Yami. 2008. Matching livestock systems with available feed resources in the Bale Highlands of Ethiopia. Outlook on Agriculture. 37(2): 105-110.

International Journal of Research Studies in Agricultural Sciences (IJRSAS)

Page | 38 
Agronomic Performance, Dry Matter Yield and Nutritional Value of Desho (Pennisetum Pedicellatum) and Setaria (Setaria Sphacelata) Grasses Mixed with Greenleaf Desmodium (Desmodium Intortum) at Different Harvesting Time

[21] Stapleton J. 2016. Unlocking the potential of Ethiopia's livestock sector: growth, jobs and environmental sustainability.In"https://news.ilri.org/2016/02/04/unlocking the potential- of-the-livestocksector-Ethiopia/".

[22] Sturludottir E; Brophy C; Elanger GB; Gustavsson AM; Jørgensen M; Lunnan T and Helgadotti, A. 2013. Benefits of mixing grasses and legumes for herbage yield and nutritive value in Northern Europe and Canada. The journal of the British Grassland society. 12037: 1-12.

[23] Watson D T and Watson MA. 1954. Comparative Physiological Studies on the Growth of Field Crops. Ann. Appl. Biol. 40: 16.

[24] Yaynshet Tesfay. 2010. Feed Resources Available in Tigray Region, North Ethiopia, For Production of Export Quality Meat and Livestock Addis Ababa Ethiopia. 9-16p.

[25] Zaman Q, M N Hussain, A Aziz and K Hayat. 2006. Performance of high yielding Oat varieties under Agro-Ecological condition of D. I. Khan. J. Agric. Res. 44: 29-35.

Citation: Minichl Yegrem, et.al, "Agronomic Performance and Dry Matter Yield of Desho (Pennisetum Pedicellatum) and Setaria (Setaria Sphacelata) Grasses Mixed with Greenleaf Desmodium (Desmodium Intortum) at Different Harvesting Time” International Journal of Research Studies in Agricultural Sciences (IJRSAS), 2019; 5(8), pp. 31-39, http://dx.doi.org/10.20431/2454-6224.0508005

Copyright: (c) 2019 Authors. This is an open-access article distributed under the terms of the Creative Commons Attribution License, which permits unrestricted use, distribution, and reproduction in any medium, provided the original author and source are credited. 